\title{
Mapping European Population Movement through Genomic Research
}

\author{
Patrick J. Geary and Krishna Veeramah*
}

This article reviews scientific publications that have attempted to use genetic and genomic data in order to investigate European migrations between the fourth and ninth centuries. It considers early single-locus studies that used mtDNA and y-chromosome data. These studies were successful in formulating hypotheses concerning migration and heterogeneity, primarily between the Continent and the British Isles and Iceland, but could only examine a small portion of the entire genetic inheritance. The article continues with a presentation of more recent genome-wide studies. In particular, it evaluates the problems of using modern genomic data to understand past migratory processes, arguing that modern DNA is a problematic source for understanding population histories of the past fifteen hundred years and urges the sequencing and analysis of ancient DNA. It also presents some of the problems of research teams that did not include archaeologists and historians as integral participants in the planning, collection, and evaluation of data. It concludes with a brief outline of the authors' current project that examines migration between Pannonia and Italy in the sixth century.

Keywords: genomics; migration; ancient DNA; population genetics; Langobards.

In 2008 Novembre et al. published an extraordinary map of the genetic diversity of Europe in the journal Nature. ${ }^{1}$ Utilizing data from the Population Reference Sample (POPRES) project, the authors examined 1,387 European individuals genotyped at ca. 500,000 single-nucleotide polymorphisms (SNPs) from across the genome. They then used principal components analysis (PCA) to summarize the observed genetic variation. Though levels of genetic variation amongst Europeans are generally very low, when plotting the two main components explaining most variation in the data on a simple xy-axis, it becomes immediately apparent that the result bears a remarkable similarity to a geographic map of Europe, even though knowledge of the geographic origins of the samples was not included in the original PCA. The continental regions of Europe are clearly visible, as are the British Isles and the Iberian and Italian peninsulas.

\footnotetext{
* Correspondence details: Patrick Geary, School of Historical Studies, Institute of Advanced Study, 1 Einstein Drive, Princeton, N.J. 08540, USA. Email: geary@ias.edu.

1 Novembre et al., Genes Mirror Geography within Europe.
} 
Novembre et al. concluded that "we find a close correspondence between genetic and geographic distances; indeed, a geographical map of Europe arises naturally as an efficient two-dimensional summary of genetic variation in Europeans. $\aleph^{2}$ One might trivialize these conclusions as stating simply that people have sex with people who are geographically proximate to them (in population genetics parlance this pattern would be summarized as "isolation-by-distance«). However, at a more serious level, it suggests that the population of Europe, while containing meaningful and recognizable differences, has been largely static: while some individuals in the study appear "out of place" (for example, the one Slovakian individual appears within the "southern Italian « cluster), one sees no evidence of major population movements, isolated populations, migrations, or other abnormalities that might put one population genetically closer to another, more geographically distant population. One does not observe, for example, a closer relationship between South and North Slavs than between North Slavs and North Germans and South Slavs and Italians or Hungarians. The latter, while speaking a language that is clearly an isolate, have a genetic profile that fits exactly where it should between Slavic, Germanic, and Romance speakers.

What are the implications of Novembre et al.'s research for understanding the history of Europe's population across centuries and even millennia? First, we need to account for certain limitations of the underlying data: since the individuals are identified only by nationality and language, it is not possible to know if a German was from Passau or Hamburg, or if an Italian was from Alto Adige or Naples, and thus the geographical coordinates of the individuals lack resolution. Second, this is a database collected largely from people who happened to pass through clinics in London or Lausanne and who agreed to be genotyped. Thus it is unlikely to be representative of local populations, and particularly from regions of Europe from which few individuals travel to major cities.

Nevertheless, such a map poses a fundamental challenge to the history of European demographics. We know that since first being colonized by Paleolithic hunter-gatherers around 40,000 years ago, Europe underwent various periods of major population movement and replacement during the Neolithic and Bronze Age. Recent paleogenomic studies have demonstrated that these prehistorical events left major signatures of admixture in modern Europe genomes, with Lazaridis et al. identifying the contribution of at least three ancestral populations that entered the continent at slightly differing times and that formed the basis of contemporary European genetic variation. ${ }^{3}$

Yet, nowhere in Novembre et. al.'s map can one find clear evidence of the migrations, the population exchanges, or the diffusions of more recent centuries, particularly those of the so-called "migration age (fourth to ninth centuries of the Common Era) that we are accustomed to encountering in our historical texts as well as in our archaeological work.

However, it is important to recognize that this map represents only one way of summarizing a particular type of modern genomic data, and to appreciate that signals of more recent demographic events involve migrations amongst populations that are genetically quite similar, since even northwestern and southeastern Europeans demonstrate only very subtle 
genetic differences. Such recent events would be expected to leave very small genomic signatures in modern genomes than the prehistorical events described above, which involved mixing between populations that had previously been separated by tens of thousands of years and thus developed substantial genomic differentiation. Therefore, more sophisticated analyses would be required to make inferences for more recent periods in European history using modern genetic data.

Some scholars believe that such analyses are possible, and a number of intriguing studies using modern genetic data attempt to clarify the impact of these historically attested population movements. The most intensively studied events have focused on the Anglo Saxon migrations and later Danish invasions and migrations into the British Isles at the end of Antiquity and in the early Middle Ages. Only recently have geneticists begun to investigate continental migration within the last 2,000 years.

The pioneering studies of this type concentrated on the non-recombinant portion of the human genome, that is, mitochondrial DNA inherited intact from mother to daughter, and that portion of the Y-chromosome passed without recombination from father to son. Today the results of these studies, relying as they did on single loci, are seen as too limited to be more than suggestive hypotheses. Nevertheless they raised issues that more advanced genomic studies are still addressing. A study by Michael Weale et al. investigating the likelihood of mass migration from the Continent to Britain at the end of Antiquity examined microsatellites in Y-chromosomes from 313 males in central England and Wales and 94 from Norway and Friesland. ${ }^{4}$ The results showed little difference in haplotype frequencies within Central England and no significant differences between Friesland and Central England while finding highly significant differences between the Welsh and English sites. What models of population migration might explain these findings? Assuming complete genetic identity at the time of the Neolithic and no background migration, the results can be explained by a mass migration from the continent that replaced between $65 \%$ to $100 \%$ of the Y-chromosomes in the Central English gene pool but none in Wales. If one assumes a background migration of $0.1 \%$ (still a very high estimate) plus a one-time mass migration, the mass migration contribution widens from $50 \%$ to $100 \%$. In a follow-up study, some of the same scientists, joined by the archaeologist Heinrich Härke, estimated that if a mass migration ca. 1,500 YBP alone was invoked to explain the modern English gene pool, this would have had to be on the order of around 500,000 men. This number is entirely unrealistic given archaeological evidence as well as what we know of early medieval demographics. ${ }^{5}$ As an alternative explanation, they ran computer simulations postulating different original sizes of migrant and indigenous populations, but assigning a reproductive advantage to the migrants as the new conquerors of Eastern and Central Britain during 15 generations, roughly the period during which Anglo-Saxon laws gave a higher value to Saxons than to indigenous Britons. Their conclusions were that with an initial migrant population of only $10 \%$ and a selective reproductive advantage of 1.5 , the socially and economically advantaged Saxons could have reached a level of $50 \%$ of the Y-chromosome gene pool within 15 generations. 
A somewhat contradictory conclusion was reached by Cristian Capelli et al., who compared 1,722 Y-chromosomes from 25 small British urban areas with Danish, Norwegian, German, and Irish data. ${ }^{6}$ With this different sampling approach, the team found that Southern England, the region presumably most heavily occupied by Anglo Saxon migrants, showed relatively little non-indigenous y-chromosomal influence. The most significant continental contribution to the Y-chromosomal profile of Great Britain in their study seems to have been that of the Danes in the north.

The models selected in the above-discussed studies derived from modern demographic studies and to some extent from estimations of numbers of migrants based on archaeology. Geneticists in Ireland took a quite different approach when attempting to estimate the impact of Scandinavian Y-chromosome DNA in the contemporary Irish population. McEvoy et al. investigated this question by adopting another model: surnames. ${ }^{7}$ The research team examined Y-chromosome diversity within a cohort of 47 Irish men bearing 26 surnames of putative Norse origin selected from geographic areas in which the Norse were known to have settled in the ninth and tenth centuries. The results were striking. On the one hand, while individuals bearing surnames such as Doyle had Y-chromosome types so different from each other that one must postulate multiple founders; others such as Arthur, Hanrik, and Gohery each bore types that were identical, suggesting a single origin for the individuals who possessed these surnames. On the other hand, no correlation was found between the Irish Y-chromosomes and the theoretical Scandinavian paternal population. Tests indicated a roughly $90 \%$ plus Irish contribution.

In Great Britain, surnames do not begin until several centuries after their appearance in Ireland and well after the end of the Viking presence in England. Nevertheless a similar study was undertaken for Wirral and West Lancashire, regions in Northwest England that, according to written evidence, were heavily occupied by Scandinavian settlers. ${ }^{8}$ The study used two samples: a "modern" sample based simply on two generations of residence in the area and a "medieval" sample of individuals who not only had male ancestors who had resided in the regions for two generations but carried surnames present in the region prior to 1572 . Interestingly the medieval sample was much more similar to modern Scandinavians, and consistent with the written evidence.

The differing results of these two studies raise questions about the nature of Viking conquest and settlement in the British Isles, but also about the approaches to elucidating the genetic evidence of these populations. Did Norse settlement in Ireland follow a different pattern from that in Great Britain, or were the Norse expelled from Ireland, as written sources suggest, in 902? Or could it be that the samples, analyses, and models used in one or another of these studies inadvertently provided data inadequate to judge the impact of Norse settlements in the two regions? The latter possibility makes one want to find a more direct way of approaching and analyzing the genetic impact of early medieval migrations.

The tentative conclusions of all of these pioneering studies are certainly plausible, but one can see how much depends on the appropriate selection of samples, the reliance on necessarily simplified if not simplistic models, assumed rates of background migration, and even 
assumptions from archaeology and textual research that themselves are extraneous sources of model-building. Adjustments in any of these can result in quite different results. A more fundamental problem lies in the focus on a single locus, either mtDNA or the Y-chromosome, to establish population history. Unfortunately, a single locus provides only a miniscule portion of an individual's ancestry: every individual has two parents, four grandparents, eight great-grandparents, sixteen great-great grandparents, etc. Tracing one single line of descent across fifteen hundred years actually provides very little information about the genetic diversity of ancestral populations and unintentionally reinforces a tendency to essentialize complex hybrid populations into simple categories. In recent years, technical advances in SNP microarrays and whole genome sequencing has made it possible to move beyond single-locus studies and to look across the entire genome.

Building on some of this early single-locus research a recent study examined genome-wide SNP data from ca. 2,000 individuals from rural areas across the British Isles. ${ }^{9}$ Much like the results of Novembre et al., geographic location dominates how genetic variation is apportioned, consistent with isolation-by-distance. However, incidence of above-average levels of differentiation via genetic clusters of individuals are observed, for example between Orkney, Wales and everywhere else. Even finer delineation of geographical regions is observed as one looks at increasing hierarchical levels of clustering. Mimicking the early single-locus studies by comparing modern European individuals, they associated these clusters with certain historical migrations, asserting "clear signals of some of the known historical migrations and settlements, including the Saxons and Norse Vikings « ${ }^{10}$ (via northern German/Danish and Norwegian populations respectively). They also estimated that "Saxon ancestry in C/S [Central/Southern] England as very likely to be under 50\%, and most likely in the range $10 \%-40 \%$. However, they also acknowledged that "we must use modern-day groupings, in Europe and the UK, as surrogates for the sources and results of major migration events, ${ }^{11}$ identifying the major weakness of their study despite the use of highly sophisticated analytical methods.

Despite certain weaknesses, islands such as the UK and Ireland, being more isolated from other populations, represent somewhat unique opportunities to identify migrational input from an outside source via genetic data. As a consequence, relatively few studies have attempted to use modern genome-wide data to assess early medieval migration within the Continent. Ralph and Coop reanalyzed the POPRES data from Novembre et al. to look for specific chromosomal regions shared between pairs of individuals from the same ancestor in the past (known as tracts of identity-by-descent or IBD, not to be confused with isolationby-distance $)^{12}$. They found that while in general pairs of individuals from the same location shared larger IBD tracts (consistent with the interpretation of Novembre et al. of isolation-by-distance), almost all European individuals, even when separated by large geographic distances ( $>2 \mathrm{~km}$ ), shared hundreds of ancestors within the last 3,000 years.

One of the more interesting patterns was that individuals from across eastern Europe shared a significantly higher number of IBD tracts than expected, which they determined was consistent with increased shared ancestry of a population from 1,000-2,000 years ago. 
The authors speculated that this may be the result of the expansion of Slavs during the migration period, and also associated the Huns in this movement because of non-Slavic modern populations in Hungary and Romania also contributing to this signal. However, they noted that "additional work and methods would be needed to verify this hypothesis." They also observed a lower rate of such shared ancestry from this point in time in France, Italy and the Iberian peninsula, interpreting this as possible evidence that »Germanic migrations/invasions « involved smaller amounts of population replacement.

Another study on European genome-wide data by Busby et al. identified substantial evidence of widespread admixture in Europe dating towards the end of the first millennium involving a population that they claim acts as a Slavic source (modern Lithuanians) $;^{13}$ they linked these events with the Völkerwanderung (a concept, incidentally, now increasingly discarded by historians). While the robustness of this precise conclusion is questionable, it does appear to support the results of Ralph and Coop that this general period of time may be important with regard to the structuring of modern European genetic diversity.

However, while these studies offer promising directions of research, they must necessarily assume that the living subjects from whom DNA is collected are direct descendants of the populations whose movements, dispersal, or interactions they wish to study. Can we be so sure that if all four grandparents came from the same village, that their ancestors had been in that village since time immemorial, or at least since the Danes, Anglo-Saxons, Huns, or Slavs arrived? Over centuries and millennia, populations do not necessarily remain stable. Subsequent internal migrations, the introduction of new genetic material through intermarriage with other communities, the forced resettlement of slaves or dependent labor, all have the potential to change the genetic profile of a population in a very dynamic manner that cannot easily be accounted for by population genetic models.

Perhaps even more significant an obstacle to working backward from modern DNA is the problem that the modern population will represent only a portion of the historical population, that portion which for whatever reason was successful in transmitting its genetic data to the present. For presentist-minded scientists, who naturally want to understand the genetic makeup of contemporary European populations, this is unproblematic. However, it poses a serious problem for historians who want to understand not just the present but rather the alterity of the past. Thus, modern DNA is likely to represent only a portion of the genetic diversity of past populations. It is, in essence, a way to study the winners, and ignores the losers in genetic history, regardless of how important they may have been in changing history.

A few studies have highlighted how quickly genetic profiles can change because of demographic effects, underlining the lack of inferential power when relying only on modern DNA analysis for historical research. Helgason et al. have performed extensive research on both modern and ancient DNA from Iceland. ${ }^{14}$ Comparing Icelanders with Norwegians on the one hand, and Irish and Scots on the other, they found that roughly $75 \%$ of founding Icelandic males were of Scandinavian origin and $25 \%$ of Irish or Scots, while the majority of female lineages had Gaelic origins and only about $37 \%$ Norse. When they compared ancient DNA extracted from Viking-age burials with that of the modern population however, they found that more than 50

14 Helgason et al., Estimating Scandinavian and Gaelic Ancestry; Helgason et al., MtDNA and the Islands of the North Atlantic; Helgason et al., Sequences From First Settlers. 
$\%$ of the original genetic diversity in the founding medieval population was not represented in the modern Icelandic population. Genetic drift appears to have had an enormous influence on the genetic profile of modern Iceland, and thus understanding the differential contributions of Y-chromosomal and mtDNA in the migratory population needs to take into account not only contemporary populations but, when possible, ancient DNA as well.

More recently, a preliminary study by our research team led by Stephanie Vai and Silvia Ghirotto looked at the mtDNA from sixth century cemeteries in the Piedmont and compared it with contemporary samples from the same region. ${ }^{15}$ We found strong evidence for discontinuity with regard to matrilineal genetic diversity between the early Middle Ages and these present populations in all but one case. This, along with the studies of Iceland described above, suggests that 1,500 years of history do matter with regard to genetic diversity. Thus, while modern genetic research is significant for a spectrum of issues involving health and possibly history, assumptions about the relationship between present and past populations must be tested against ancient DNA collected from the individuals we are actually attempting to study, rather than relying automatically on modern proxies.

This is now beginning to be realized not just at the mtDNA and Y-chromosome levels, but also by examining whole genome data from ancient individuals, which should provide considerably more power to make inferences. (As described above, such data has revolutionized our understanding of prehistorical Eurasia.) Schiffels et al. were recently able to sequence the whole genomes from 10 individuals in Cambridge dating to the late Iron Age $(n=3)$ as well as the early $(n=4)$ and middle $(n=3)$ Anglo-Saxon periods. ${ }^{16}$ By developing a novel method that examines rare shared alleles between ancient and modern samples, they demonstrated that while middle Anglo-Saxons were genetically close to modern Dutch and Danish populations, the older Iron Age individuals showed a much greater diversity of ancestors from across Northern Europe. The early Anglo-Saxon samples, despite demonstrating similar burial positions and grave goods, showed intriguing evidence of heterogeneous ancestry, with one individual being similar to the Iron Age samples, one being a likely recent immigrant, and two individuals probably being of mixed ancestry. Interestingly, in general modern British individuals appear to share more ancestry with the older Iron Age samples, with the greatest Anglo-Saxon similarity occurring in modern eastern England. While certainly more work is needed, it is clear that the patterns of migration and admixture over the time span considered by these ancient genomes were very complex, with the authors stating that their data "show that early medieval migration took a variety of forms and that these migrants integrated with the incumbent population in different ways ${ }^{17}$. Such a resolution is only possible with ancient genomic (paleogenomic) data.

While the Schiffels et al. study is somewhat small in scale with regards to size and breadth of sampling, clearly, there are no longer major technical hurdles that would prevent the characterization of hundreds to thousands of paleogenomes from the historical era. We are already at this point with prehistorical specimens, which are generally harder to acquire and have less endogenous DNA. ${ }^{18}$ Thus, it should be possible to amass similar data for more

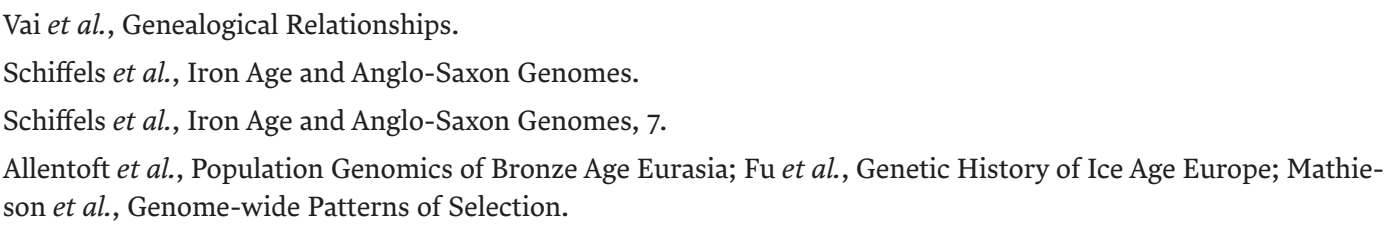


recent periods. Using such data, we then could ask what a genetic map of Europe would look like if, instead of relying on twenty-first century European genomes as in Novembre et al., it examined genomes from people who actually lived during the so-called migration age. Better yet, what if we could produce a series of such maps at regular intervals across the centuries such that we could see changes in how genetic diversity is distributed across the continent? Might we then see, rather than John Novembre's »isolation-by-distance«, evidence of recent migrations resulting in geographically separate populations with close genetic profiles? Thinking still further, what would an ancient genomic map of all of Eurasia look like at discrete moments in time? Would we see the effects of the great Steppe empires of the Xongnu, Huns, and Mongols? Would we see the presence of whole populations displaced as the result of wars or political decisions? Would men and women have different migration histories? With genome-wide ancient DNA we should be able to not only identify such events and processes, but quantify them, estimating parameters such as sizes of ancestral populations and the magnitude of population movements.

These are the kinds of questions that our research team is attempting to answer on a very preliminary and modest scale by doing deep genetic analysis of skeletal remains of over 1,200 sixth and early seventh-century individuals from what are generally seen as Langobard cemeteries in the former Pannonia (Austria, Hungary, Moravia) and Italy from the sixth century. ${ }^{19}$

Our decision to concentrate on Langobards had nothing to do with an intrinsic interest in Langobards, Pannonia, or Italy as such. It was driven by our desire to find a population with abundant archaeological and historical evidence that could be used to construct models of population histories and that could then be compared with those derived from population genetics. Of all of the various peoples who were reputed to have migrated into the Roman Empire at the end of Antiquity, the Langobards are the latest and the best documented. Accounts by Marius of Avenches, ${ }^{20}$ Gregory of Tours, ${ }^{21}$ and especially Paul the Deacon, ${ }^{22}$ describe the early history of the Langobards from their appearance in Pannonia ca. 500 until their conquest of Italy in the 560s. Whether or not these texts are accurate, they provide what might be called a model of Langobard migration that can then be compared with other types of evidence. ${ }^{23}$

Archaeologists studying sixth-century cemeteries throughout the region classify as Langobard hundreds of sites, based on a mixture of archaeological and historical sources. ${ }^{24} \mathrm{Mo-}$ reover, they attribute the appearance in Northern Italy of burial forms and grave goods similar to those from the regions of Pannonia to the arrival of Langobards. Our project remains agnostic concerning such identifications, based either on textual or archaeological evidence.

o Marius of Avenches, Chronica, ed. Mommsen, 238.

21 Gregory of Tours, Historiarum Libri X, IV, 41, ed. Krusch and Levison, 174.

22 Paul the Deacon, Historia Langobardorum, II, 7, ed. Waitz, 78.

23 On Langobard history in general see Ausenda et al. (eds.), Langobards before the Frankish Conquest; Pohl and Erhart (eds.), Langobarden - Herrschaft und Identität.

24 On Langobard archaeology: Landschaftsverband Rheinland and Rheinisches Landesmuseum Bonn, Langobarden; Tejral et al. (eds.), Langobardische Gräberfelder in Mähren; Bóna and Horváth, Langobardische Gräberfelder in West-Ungarn; Pejrani Baricco (ed.), Presenze Langobarde; Bemmann and Schmauder (eds.), Kulturwandel in Mitteleuropa. 
We are not claiming that any of our samples are "Langobards." After all this term could be cultural, political, or ethnic. Clearly people both in Pannonia and in Italy would have identified themselves as Langobards, but we cannot be certain that all of the individuals buried in this way would have done so, or that they would have identified themselves as Langobards for all purposes and on all occasions. A legal identity could be quite different from a political adhesion, a linguistic tradition, or a cultural practice. However, these cultural patterns present another model that can be compared with the historical record and the genetic record to construct a comprehensive image of the population of the region.

Again, the focus of our study is not one of Langobard identity: with apologies to the numerous, excellent scholars studying early medieval ethnic identities, our project offers no answers to their debate. It does, however, have the potential to examine whether, in the course of the sixth century, closely interrelated communities existed in modern Hungary and the surrounding region who differed in their genetic profile from their neighbors, thus suggesting recent arrival or long-established populations. It also can determine whether populations south of the Alps that followed the same cultural norms in burying their dead were more closely related to those practicing similar traditions in the North and East, or whether, despite a unique cultural identity manifested in their burial customs, they sprang from the same stock as their Italian neighbors. Our project offers, in other words, a different way of conceptualizing space, this time in terms of genetic affinities and that can be compared with other spaces such as those constructed by material culture, language, law, and politics.

This work is necessarily interdisciplinary, something notably lacking in the majority of genetic studies. The Ralph and Coop study, while highly rigorous at the level of the population genetic analysis, included no historians or archaeologists, and the only historical literature cited, presumably to »identify « the Hunnic contribution to European population, was a general history of Europe, ${ }^{25}$ a survey of Slavic history, ${ }^{26}$ and two articles in the New Cambridge Medieval History. ${ }^{27}$ The Busby et al. study also included no historians or archaeologists on its team, and the only historical literature cited was a Penguin History of the World, Peter Heather's survey of the Early Middle Ages, and a survey of Muslims in Italy. ${ }^{28}$ Unlike these studies, designed and executed exclusively by geneticists who then look through a few general historical handbooks to try to find stories that might explain their data, historians and archaeologists are integrated from the start in our project. Their role is both to develop the historical questions that we seek to answer and also to identify and understand the nature of the specimens that we are analyzing. However, just as geneticists cannot execute the project in isolation, historians cannot simply ask geneticists to confirm the stories they find in their texts. And certainly archaeologists must develop independent typologies and chronologies for their data and not rely on either textual sources or genetics to identify and date material culture ensembles. We believe then that such research must be from its inception an intimate collaboration among these disciplines; together, our team has developed a series of historical questions that we hope genetic research might answer.

25 Davies, Europe.

26 Barford, Early Slavs.

27 Halsall, Barbarian Invasions; Kobyliński, Slavs.

28 Heather, Empires and Barbarians; Metcalfe, Muslims of Medieval Italy; Roberts, New Penguin History of the World. 
Essentially, we want to understand the social structure of the militarized communities within and without the Empire in the sixth century. This means determining the genetic relationships that existed among individuals buried in what have been termed Langobard and non-Langobard cemeteries. It also requires investigating the biological relationships between individuals buried in neighboring "Langobard « and non-»Langobard « cemeteries. Do these communities show any significant genetic structure or are they simply part of the same biological community? If there is some differentiation and we find evidence of gene-flow between groups, is there evidence that this differentiation is sex-biased? Do all of these characteristics differ between presumed Langobard communities in Pannonia and those in Italy? Are the populations that are buried in so-called Langobard cemeteries primarily a portion of the indigenous population that took on the cultural, social, and behavioral models of the new powers in Italy? And finally, is there evidence of genetic continuity between pre-(Pannonia) and post-(Italy) migration "Langobard " cemeteries?

These are large questions, and it will take many years and millions of euros to properly sequence skeletal remains from the over 1,200 graves in our sample. We must then analyze our data using statistical methodologies developed by population geneticists, and then confront the results with those developed from the analysis of stable isotopes, historical evidence, and cultural archaeology. Our project, although under way for four years, is still at the beginning. However we hope, through close collaboration between disciplines and mutual respect for the contributions of historians, geneticists, and archaeologists, to begin to uncover the demographic history of the migration period and in so doing contribute to a map similar to that produced by Novembre et al., but of Europe's population a millennium and a half ago.

\section{Acknowledgements}

The authors acknowledge support for this work from NSF award 1450606. 


\section{References}

Allentoft, Morten E., Sikora, Martin, Sjögren, Karl-Göran, Rasmussen, Simon, Rasmussen, Morten, Stenderup, Jesper, Damgaard, Peter B., Schroeder, Hannes, Ahlström, Torbjörn, Vinner, Lasse, Malaspinas, Anna-Sapfo, Margaryan, Ashot, Higham, Tom, Chivall, David, Lynnerup, Niels, Harvig, Lise, Baron, Justyna, Della Casa, Philippe, Dąbrowski, Paweł, Duffy, Paul R., Ebel, Alexander V., Epimakhov, Andrey, Frei, Karin, Furmanek, Mirosław, Gralak, Tomasz, Gromov, Andrey, Gronkiewicz, Stanisław, Grupe, Gisela, Hajdu, Tamás, Jarysz, Radosław, Khartanovich, Valeri, Khokhlov, Alexandr, Kiss, Viktória, Kolář, Jan, Kriiska, Aivar, Lasak, Irena, Longhi, Cristina, McGlynn, George, Merkevicius, Algimantas, Merkyte, Inga, Metspalu, Mait, Mkrtchyan, Ruzan, Moiseyev, Vyacheslav, Paja, László, Pálfi, György, Pokutta, Dalia, Pospieszny, Łukasz, Price, T. Douglas, Saag, Lehti, Sablin, Mikhail, Shishlina, Natalia, Smrčka, Václav, Soenov, Vasilii I., Szeverényi, Vajk, Tóth, Gusztáv, Trifanova, Synaru V., Varul, Liivi, Vicze, Magdolna, Yepiskoposyan, Levon, Zhitenev, Vladislav, Orlando, Ludovic, Sicheritz-Pontén, Thomas, Brunak, Søren, Nielsen, Rasmus, Kristiansen, Kristian and Willerslev, Eske, Population Genomics of Bronze Age Eurasia, Nature 522 (2015) 167-172. Retrieved on 10 September 2016: www.nature.com/ nature/journal/v522/n7555/full/nature14507.html.

Ausenda, Giorgo, Delogu, Paolo and Wickham, Chris (eds.), The Langobards before the Frankish Conquest: An Ethnographic Perspective, Studies in Historical Archaeoethnology 8 (Woodbridge, 2009).

Barford, Paul M., The Early Slavs: Culture and Society in Early Medieval Eastern Europe (Ithaca, 2001).

Bemmann, Jan and Schmauder, Michael (eds.), Kulturwandel in Mitteleuropa : Langobarden, Awaren, Slawen: Akten der Internationalen Tagung in Bonn vom 25. bis 28. Februar 20o8, Kolloquien zur Vor- und Frühgeschichte 2 (Bonn, 2008).

Bóna, István and Horváth, Jolán B., Langobardische Gräberfelder in West-Ungarn (Budapest, 2009).

Bowden, Georgina R., Balaresque, Patricia, King, Turi E., Hansen, Ziff, Lee, Andrew C., Pergl-Wilson, Giles, Hurley, Emma, Roberts, Stephen J., Waite, Patrick, Jesch, Judith, Jones, Abigail L., Thomas, Mark G., Harding, Stephen E. and Jobling, Mark A., Excavating Past Population Structures by Surname-Based Sampling: the Genetic Legacy of the Vikings in Northwest England, Molecular Biology and Evolution 25/2 (2008) 301-309. Retrieved on 11 September 2016: mbe.oxfordjournals.org/content/25/2/301.full.pdf+html.

Busby, George B. J., Hellenthal, Garrett, Montinaro, Francesco, Tofanelli, Sergio, Bulayeva, Kazima, Rudan, Igor, Zemunik, Tatijana, Hayward, Caroline, Toncheva, Draga, Karachanak-Yankova, Sena, Nesheva, Desislava, Anagnostou, Paolo, Cali, Francesco, Brisighelli, Francesca, Romano, Valentino, Lefranc, Gerard, Buresi, Catherine, Chibani, Jemni Ben, Haj-Khelil, Amel, Denden, Sabri, Ploski, Rafal, Krajewski, Pawel, Hervig, Tor, Moen, Torolf, Herrera, Rene J., Wilson, James F., Myers, Simon and Capelli, Cristian, The Role of Recent Admixture in Forming the Contemporary West Eurasian Genomic Landscape, Current Biology 25 (2015) 2518-2526.

Capelli, Cristian, Redhead, Nicola, Abernethy, Julia K., Gratrix, Fiona, Wilson, James F., Moen, Torolf, Hervig, Tor, Richards, Martin, Stumpf, Michael P.H., Underhill, Peter A., Bradshaw, Paul, Shaha, Alom, Thomas, Mark G., Bradman, Neal and Goldstein, David B., A Y Chromosome Census of the British Isles, Current Biology 13 (2003) 979-984.

Davies, Norman, Europe: A History (New York, 1996). 
Fu, Qiaomei, Posth, Cosimo, Hajdinjak, Mateja, Petr, Martin, Mallick, Swapan, Fernandes, Daniel, Furtwängler, Anja, Haak, Wolfgang, Meyer, Matthias, Mittnik, Alissa, Nickel, Birgit, Peltzer, Alexander, Rohland, Nadin, Slon, Viviane, Talamo, Sahra, Lazaridis, Iosif, Lipson, Mark, Mathieson, Iain, Schiffels, Stephan, Skoglund, Pontus, Derevianko, Anatoly P., Drozdov, Nikolai, Slavinsky, Vyacheslav, Tsybankov, Alexander, Grifoni Cremonesi, Renata, Mallegni, Francesco, Gély, Bernard, Vacca, Eligio, González Morales, Manuel R., Straus, Lawrence G., Neugebauer-Maresch, Christine, Teschler-Nicola, Maria, Constantin, Silviu, Moldovan, Oana Teodora, Benazzi, Stefano, Peresani, Marco, Coppola, Donato, Lari, Martina, Ricci, Stefano, Ronchitelli, Annamaria, Valentin, Frédérique, Thevenet, Corinne, Wehrberger, Kurt, Grigorescu, Dan, Rougier, Hélène, Crevecoeur, Isabelle, Flas, Damien, Semal, Patrick, Mannino, Marcello A., Cupillard, Christophe, Bocherens, Hervé, Conard, Nicholas J., Harvati, Katerina, Moiseyev, Vyacheslav, Drucker, Dorothée G., Svoboda, Jiř́, Richards, Michael P., Caramelli, David, Pinhasi, Ron, Kelso, Janet, Patterson, Nick, Krause, Johannes, Pääbo, Svante and Reich, David, The Genetic History of Ice Age Europe, Nature 34 (2016) 200-205. Retrieved on 10 September 2016: www.nature.com/ nature/journal/v534/n7606/full/nature17993.html.

Geary, Patrick, Rethinking Barbarian Invasions through Genomic History, Hungarian Archaeology (Autumn 2014) 1-8. Retrieved on 11 September 2016: www.hungarianarchaeology. hu/wpcontent/uploads/2014/11/eng_geary_14O.pdf.

Gregory of Tours, Historiarum Libri X, ed. Bruno Krusch and Wilhelm Levison, MGH SSRM 1 (Hannover, 1951).

Halsall, Guy, The Barbarian Invasions, in: Paul Fouracre (ed.) The New Cambridge Medieval History, Vol. 1: c. 500 - c. 700 (Cambridge, 2005) 38-55.

Heather, Peter, Empires and Barbarians (Oxford, 2009).

Helgason, Angar, Sigurðardóttir, Sigrún, Nicholson, Jayne, Sykes, Bryan, Hill, Emmeline W., Bradley, Daniel G., Bosnes, Vidar, Gulcher, Jeffery R., Ward, Ryk and Stefánsson, Kári, Estimating Scandinavian and Gaelic Ancestry in the Male Settlers of Iceland, American Journal of Human Genetics 67 (2000) 697-717.

Helgason, Angar, Hickey, Eileen, Goodacre, Sara, Bosnes, Vidar, Stefánsson, Kári, Ward, Ryk and Sykes, Bryan, MtDNA and the Islands of the North Atlantic: Estimating the Proportions of Norse and Gaelic Ancestry, American Journal of Human Genetics 68 (2001) 723-737.

Helgason, Agnar, Lalueza-Fox, Carles, Ghosh, Shyamali, Sigurðardóttir, Sigrún, Sampietro, Maria Lourdes, Gigli, Elena, Baker, Adam, Bertranpetit, Jaume, Árnadóttir, Lilja, Dorsteinsdottir, Unnur and Stefánsson, Kári, Sequences from First Settlers Reveal Rapid Evolution in Icelandic mtDNA Pool, PLoS Genetics 5/1 (2009). Retrieved on 11 September 2016: journals.plos.org/plosgenetics/article?id=10.1371/journal.pgen.1000343.

Kobyliński, Zbigniew, The Slavs, in: Paul Fouracre (ed.) The New Cambridge Medieval History, Vol. 1: c. 500 - c. 700 (Cambridge, 2005) 524-544.

Landschaftsverband Rheinland, Rheinisches Landesmuseum Bonn (eds.), Die Langobarden: Das Ende der Völkerwanderung: Katalog zur Ausstellung im Rheinischen LandesMuseum Bonn 22.8.2008-11.1.2009 (Darmstadt, 2008). 
Lazaridis, Iosif, Patterson, Nick, Mittnik, Alissa, Renaud, Gabriel, Mallick, Swapan, Kirsanow, Karola, Sudmant, Peter H., Schraiber, Joshua G., Castellano, Sergi, Lipson, Mark, Berger, Bonnie, Economou, Christos, Bollongino, Ruth, Fu, Qiaomei, Bos, Kirsten I., Nordenfelt, Susanne, Li, Heng, Filippo, Cesare de, Prüfer, Kay, Sawyer, Susanna, Posth, Cosimo, Haak, Wolfgang, Hallgren, Fredrik, Fornander, Elin, Rohland, Nadin, Delsate, Dominique, Francken, Michael, Guinet, Jean-Michel, Wahl, Joachim, Ayodo, George, Babiker, Hamza A., Bailliet, Graciela, Balanovska, Elena, Balanovsky, Oleg, Barrantes, Ramiro, Bedoya, Gabriel, Ben-Ami, Haim, Bene, Judit, Berrada, Fouad, Bravi, Claudio M., Brisighelli, Francesca, Busby, George B. J., Cali, Francesco, Churnosov, Mikhail, Cole, David E. C., Corach, Daniel, Damba, Larissa, van Driem, George, Dryomov, Stanislav, Dugoujon, Jean-Michel, Fedorova, Sardana A., Gallego Romero, Irene, Gubina, Marina, Hammer, Michael, Henn, Brenna M., Hervig, Tor, Hodoglugil, Ugur, Jha, Aashish R., Karachanak-Yankova, Sena, Khusainova, Rita, Khusnutdinova, Elza, Kittles, Rick, Kivisild, Toomas, Klitz, William, Kučinskas, Vaidutis, Kushniarevich, Alena, Laredj, Leila, Litvinov, Sergey, Loukidis, Theologos, Mahley, Robert W., Melegh, Béla, Metspalu, Ene, Molina, Julio, Mountain, Joanna, Näkkäläjärvi, Klemetti, Nesheva, Desislava, Nyambo, Thomas, Osipova, Ludmila, Parik, Jüri, Platonov, Fedor, Posukh, Olga, Romano, Valentino, Rothhammer, Francisco, Rudan, Igor, Ruizbakiev, Ruslan, Sahakyan, Hovhannes, Sajantila, Antti, Salas, Antonio, Starikovskaya, Elena B., Tarekegn, Ayele, Toncheva, Draga, Turdikulova, Shahlo, Uktveryte, Ingrida, Utevska, Olga, Vasquez, René, Villena, Mercedes, Voevoda, Mikhail, Winkler, Cheryl A., Yepiskoposyan, Levon, Zalloua, Pierre, Zemunik, Tatijana, Cooper, Alan, Capelli, Cristian, Thomas, Mark G., Ruiz-Linares, Andres, Tishkoff, Sarah A., Singh, Lalji, Thangaraj, Kumarasamy, Villems, Richard, Comas, David, Sukernik, Rem, Metspalu, Mait, Meyer, Matthias, Eichler, Evan E., Burger, Joachim, Slatkin, Montgomery, Pääbo, Svante, Kelso, Janet, Reich, David and Krause, Johannes, Ancient Human Genomes Suggest Three Ancestral Populations for Present-day Europeans, Nature 513 (2014) 409-413. Retrieved on 12 September 2016: www.nature.com/nature/ journal/v513/n7518/full/nature13673.html.

Leslie, Stephen, The Fine-scale Genetic Structure of the British Population, Nature 519 (2015) 309-314. Retrieved on 11 September 2016: www.nature.com/nature/journal/ v519/n7543/full/nature14230.html.

Marius of Avenches, Chronica, ed. Theodor Mommsen, MGH AA 11 (Berlin, 1894).

Mathieson, Iain, Lazaridis, Iosif, Rohland, Nadin, Mallick, Swapan, Patterson, Nick, Roodenberg, Songül Alpaslan, Harney, Eadaoin, Stewardson, Kristin, Fernandes, Daniel, Novak, Mario, Sirak, Kendra, Gamba, Cristina, Jones, Eppie R., Llamas, Bastien, Dryomov, Stanislav, Pickrell, Joseph, Arsuaga, Juan Luís, Bermúdez de Castro, José María, Carbonell, Eudald, Gerritsen, Fokke, Khokhlov, Aleksandr, Kuznetsov, Pavel, Lozano, Marina, Meller, Harald, Mochalov, Oleg, Moiseyev, Vyacheslav, Rojo Guerra, Manuel A., Roodenberg, Jacob, Vergès, Josep Maria, Krause, Johannes, Cooper, Alan, Alt, Kurt W., Brown, Dorcas, Anthony, David, Lalueza-Fox, Carles, Haak, Wolfgang, Pinhasi, Ron and Reich, David, Genome-wide Patterns of Selection in 230 Ancient Eurasians, Nature 528 (2015) 499503. Retrieved on 12 September 2016: www.nature.com/nature/journal/v528/n7583/ full/nature16152.html.

McEvoy, Brian, Brady, Claire, Moore, Laoise T. and Bradley, Daniel G., The Scale and Nature of Viking Settlement in Ireland from Y-chromosome Admixture Analysis, European Journal of Human Genetics 14 (2006) 1288-1294.

Metcalfe, Alex, The Muslims of Medieval Italy (Edinburgh, 2009). 
Novembre, John, Johnson, Toby, Bryc, Katarzyna, Kutalik, Zoltán, Boyko, Adam R., Auton, Adam, Indap, Amit, King, Karen S., Bergmann, Sven, Nelson, Matthew R., Stephens, Matthew and Bustamante, Carlos D., Genes Mirror Geography within Europe, Nature 456 (2008) 98-101. Retrieved on 11 September 2016: www.nature.com/nature/journal/ v456/n7218/full/nature07331.html.

Paul the Deacon, Historia Langobardorum, ed. Georg Waitz, MGH SSRL (Hannover, 1878).

Pejrani Baricco, Luisella (ed.). Presenze Langobarde: Collegno nell'alto medioevo (Torino, 2004). Pohl, Walter and Erhart, Peter (eds.), Die Langobarden - Herrschaft und Identität, Forschungen zur Geschichte des Mittelalters 9 (Vienna, 2005).

Roberts, John M., The New Penguin History of the World (London, 2007).

Schiffels, Stephan, Haak, Wolfgang, Paajanen, Pirita, Llamas, Bastien, Popescu, Elizabeth, Loe, Louise, Clarke, Rachel, Lyons, Alice, Mortimer, Richard, Sayer, Duncan, Tyler-Smith, Chris, Cooper, Alan and Durbin, Richard, Iron Age and Anglo-Saxon Genomes from East England Reveal British Migration History, Nature Communications 7 (2016). Retrieved on 12 September 2016: www.nature.com/articles/ncomms10408.

Tejral, Jaroslav, Čižmář, Miloš, Stuchlík, Stanislav, Klanicová, Soňa and Klanica, Zdeněk (eds.), Langobardische Gräberfelder in Mähren, Vol. 1 (Brno, 2011).

Thomas, Mark G., Stumpf, Michael P. H. and Härke, Heinrich, Evidence of an Apartheid-like Social Structure in Early Anglo-Saxon England, Proceedings of the Royal Society B: Biological Sciences 273 (2006) 2651-2657.

Vai, Stefania, Ghirotto, Silvia, Pilli, Elena, Tassi, Francesca, Lari, Martina, Rizzi, Ermanno, Matas-Lalueza, Laura, Ramirez, Oscar, Lalueza-Fox, Carles, Achilli, Alessandro, Olivieri, Anna, Torroni, Antonio, Lancioni, Hovirag, Giostra, Caterina, Bedini, Elena, Pejrani Baricco, Luisella, Matullo, Giuseppe, Di Gaetano, Cornelia, Piazza, Alberto, Veeramah, Krishna, Geary, Patrick, Caramelli, David and Barbujani, Guido, Genealogical Relationships between Early Medieval and Modern Inhabitants of Piedmont, PLoS ONE 10/1 (2015). Retrieved 12 September 2016: journals.plos.org/plosone/article?id=10.1371/journal. pone.0116801.

Weale, Michael, Weiss, Deborah A., Jager, Rolf F., Bradman, Neil and Thomas, Mark G., Y Chromosome Evidence for Anglo-Saxon Mass Migration, Molecular Biology and Evolution 19/7 (2002) 1008-1021. 